\title{
EFEK MEDIASI SENSE OF CONTROL PADA PENGARUH SMARTPHONE ADDICTION TERHADAP ACADEMIC PROCRASTINATION (Studi Pada Siswa SMK Pasundan 1 Cianjur Jurusan Akuntansi)
}

\author{
${ }^{1}$ Dikdik Japar Sidik, ${ }^{2}$ Kurjono, ${ }^{3}$ Meta Arief, ${ }^{4}$ Budi Santoso \\ ${ }^{1234}$ FPEB, Universitas Pendidikan Indonesia \\ 1email: dikdikjaparsidik@upi.edu \\ email: kurjono@upi.edu \\ ${ }^{3}$ email: metaarief@upi.edu \\ 4email: budisantoso@upi.edu
}

\begin{abstract}
The purpose of this study was to obtain information about the mediating effect of sense of control on the influence of smartphone addiction on academic procrastination in students of SMK Pasundan 1 Cianjur majoring in accounting. The theory that underlies this research is the theory of gestalk cognitive psychology. This study uses a quantitative approach with a survey method and the instrument used is a questionnaire distributed to students of SMK Pasundan 1 Cianjur majoring in accounting with random sampling technique, and the sample collected is 123 respondents. The data analysis technique used an associative approach with a statistical measuring tool for path coefficients (parh analysis). Based on the results of research conducted on students of SMK Pasundan 1 Cianjur majoring in accounting, the results showed that smartphone addiction had no negative effect on sense of control, sense of control had a negative effect on academic procrastination, and smartphone addiction had a positive effect on academic procrastination. Smartphone addiction does not significantly affect academic procrastination through sense of control. The advice given in this study is on the smartphone addiction variable, students should reduce positive anticipation as the most dominating indicator. On the variable sense of control students must increase the ability to control attention as the lowest indicator, in addition to the academic variable procrastination students must reduce the level of personal initiative as the most dominating indicator
\end{abstract}

Key Word : Smartphone Addiction, Sense of Control, Academic Procrastintion.

\begin{abstract}
ABSTRAK
Tujuan penelitian ini adalah untuk memperoleh informasi mengenai efek mediasi sense of control pada pengaruh smartphone addiction terhadap academic procrastination pada siswa SMK Pasundan 1 Cianjur jurusan akuntansi. Teori yang mendasari penelitian ini adalah teori psikologi kognitif gestalk. Penelitian ini menggunakan pendekatan kuantitatif dengan metode survey dan istrumen yang digunakan berupa angket yang disebar kepada siswa SMK Pasundan 1 Cianjur jurusan akuntansi dengan teknik random samling, dan sampel yang terkumpul sebanyak 123 responden. Teknik analisis data menggunakan pendekatan asosiatif dengan alat ukur statistik koefisien jalur (parh analysis). Berdasarkan hasil penelitian yang dilakukan pada siswa SMK Pasundan 1 Cianjur jurusan akuntansi memperoleh hasil bahwa smartphone addiction tidak berpengaruh negatif terhadap sense of control, sense of control berpengaruh negatif terhadap academic procrastination, smartphone addiction berpengaruh positif terhadap academic procrastination. Smartphone addiction tidak berpengaruh secara signifikan terhadap academic procrastination melalui sense of control. Adapun saran yang diberikan dalam penelitian ini adalah pada variabel smartphone addiction siswa harus menurunkan antisipasi positif sebagai indikator yang paling mendominasi. Pada variable sense of
\end{abstract}


control siswa harus meningkatkan kemampuan mengendalikan perhatian sebagai indikator yang paling rendah, selain itu pada variabel academic procrastination siswa harus menurunkan tingkat inisiatif pribadi sebagai indikator yang paling mendominasi.

Kata Kunci: Smartphone Addiction, Sense of Control, Academic Procrastintion.

\section{PENDAHULUAN}

Sekolah merupakan salah satu wadah siswa untuk dapat meningkatkan kemampuan baik dari segi pengetahuan keterampilan maupun sikap. Sekolah yang dijadikan tempat pendidikan diharapkan dapat menghasilkan generasi penerus bangsa yang cerdas, kreatif dan kompetitif.

Berfokus pada jenjang Sekolah menengah atas yang notabennya adalah siswa remaja, berdasarkan teori piaget menyatakan bahwa, masa remaja merupakan masa dimana perkembangan pada aspek kognitif terjadi perubahan begitu signifikan yang mencapai taraf sampai operasi formal, sehingga kemudian segala aspek aktivitas yang dilakukan oleh siswa SMA merupakan manifestasi dari hasil berpikir logis siswa itu sendiri (Santrock, 2007).

Dalam proses pengembangan potensi diri seorang individu diharuskan adanya pola asuhan yang terarah utamanya pada fase remaja. Pola asuhan yang dikenal dengan istilah pendidikan merupakan sebuah proses usaha agar manusia dapat mengembangkan potensi dirinya dengan melalui beberapa proses yang sistematis dan terukur yang dilaksanakan berdasarkan pengakuan dari masyarakat. Menurut Yusuf dan Nur Ichsan 2011 dalam Meiliza Purwanti, Purwanti, (2016) menyatakan bahwa pendidikan merupakan sebuah lingkungan untuk dapat meningkatkan potensi dan bertanggung jawab atas asuhan yang diberikan kepada seorang individu dalam proses perkembangan potensi dari individu tersebut.

Pada pelaksanaan kurikulum 2013, terdapat banyak tuntutan terhadap peserta didik dimana peserta didik dituntut untuk lebih aktif dan kreatif, disamping itu banyak pula tugas yang harus diselesaikan oleh peserta didik dengan baik dan tepat waktu. Dipicu oleh pelaksanaan pembelajaran yang dilakukan secara daring dimasa pandemi mengakibatkan penurunan motivasi belajar siswa yang ditandai dengan adanya penundaan pekerjaan tugas yang diberikan oleh guru kepada siswa (Maison, M., Kurniawan, D. A., \& Anggraini, 2021). Penundaan akademik atau yang biasa disebut dengan prokrastinasi akademik merupakan sebuah perilaku siswa di mana siswa lebih mementingkan melakukan kegiatan yang dianggap lebih menyenangkan dan mengenyampingkan tugas akademiknya (Ferrari \& Tice, 2000). Timbulnya masalah pada skala prioritas peserta didik dalam menyelesaikan tugas akademiknya, akan menimbulkan masalah baru terhadap hasil ataupun output dari sebuah pendidikan. Dimana berdasarkan hasil penelitian dari Solomon \& Rothblum (1984) bahwa dampak dari penundaan akademik adalah adanya tugas yang tidak terselesaikan. Jikapun terselesaikan hasil dari pengerjaan tugas yang dikerjakan cenderung mendapatkan hasil yang kurang maksimal karena dikejar waktu. Selain itu menurut Meiliza Purwanti \& Purwanti (2016) dampak lain dari perilaku prokrastinasi akademik adalah timbulnya kecemasan pada diri seorang individu dalam pengerjaan tugas serta adanya kesulitan dalam berkonsentrasi karena perasaan cemas. Keadaan ini akan menimbulkan kurangnya motivasi dan kepercayaan diri pada peserta didik. Tidak dapat dipungkiri bahwa smartphone memang memberikan 
efisiensi dan kenyamanan terhadap pengguna di era modern seperti sekarang ini, namun tidak dipungkiri juga bahwa penggunaan smartphone yang berlebihan justru membawa banyak dampak buruk terhadap kehidupan sosial, gangguan pada kesehatan maupun akademis (Choi et al., 2015, Khoury et al., 2019, Kwon et al., 2013).

Sebuah riset dengan 517 siswa menengah Atas sebagai subjeknya membuktikan bahwa penggunaan smartphone yang digunakan secara berlebihan membawa dampak negatif terhadap kinerja akademis (Pierce \& Vaca, 2007). Beberapa penelitian lainnya menghasilkan kesimpulan bahwa adanya hubungan positif antara prokrastinasi akademik dengan kecanduan smartphone, artinya semakin tinggi tingkat kecanduan smartphone siswa, maka semakin tinggi pula tingkat prokrastinasi akademik siswa (Davis et al., 2002, Geng et al., 2018).

Banyaknya siswa yang melakukan prokrasitinasi akademik mengakibatkan siswa melakukan pengerjaan tugas akademiknya dengan sistem kebut semalam ( $\mathrm{Sa}$ et al., 2019). Perilaku ini yang pada akhirnya menyebabkan hasil belajar siswa tidak maksimal bahkan berpotensi siswa untuk melakukan dan perilaku menyontek tugas temannya (Umar et al., 2018).

Selain itu menurut Suharsono (2013) prokrastinasi juga disebabkan oleh rasa kontrol yang ada pada diri seorang individu seorang individu lebih memilih untuk melakukan kegiatan yang dianggap menyenangkan daripada hal yang penting. Sebagai contoh seorang peserta didik yang tidak mampu mengendalikan dirinya untuk tetap bertindak positif terhadap tugas yang diberikan oleh guru sehingga ia lebih memilih bermain daripada sekedar mengerjakan (Syahriani \& Laksmiwati 2017 Safiinatunnajah \& Fikry, 2021). Sejalan dengan itu berdasarkan hasil penelitian yang dilakukan oleh Muhid (2009) ditemukan bahwa terdapat beberapa aspek yang dapat mempengaruhi prokrastinasi diantaranya adalah rendahnya rasa kontrol diri, kesadaran diri, efikasi diri, kehormatan diri dan kecemasan sosial.

Hasil penelitian yang dilakukan oleh Krause et al. (1998) menyatakan bahwa pada umumnya rasa control memediasi hubungan dari hasil stressor. Selain itu (Zarzycka et al. (2021) menyatakan bahwa sense of control memediasi perilaku prokrastinasi. Pada dasarnya setiap individu mempunyai tingkatan kontrol diri yang berbeda-beda. Individu yang punya kontrol diri yang rendah cenderung tidak akan mempertimbangkan setiap konsekuensi dari sebuah tindakan yang diambil oleh individu itu sendiri (gottfredson dan Hirschi dalam Sabir, hlm. 11, 2007).

Grand teori digunakan dalam penelitian ini adalah teori psikologi kognitif getalk. Teori psikologi kognitif pertama kali dikemukakan Kaffa dan Kohler dari Jerman (Djamarah, 2011). Prinsip belajar menurut gestalt bahwa kegiatan belajar tergantung dari pembelajar. Belajar dikatakan penting bukan dari seorang individu mengulang hal yang sudah dipelajari, tetapi memahami arti penting belajar itu sendiri (Suryono \& Hariyanto, 2011). Hubungan teori gestalt dengan penelitian ini adalah bahwa sebuah pembelajaran dapat dikatakan berhasil manakala seseorang dapat menghubungkan belajar dengan minat dan motivasi yang didasari atas dasar rasa kontrol pada diri seorang individu. Seorang individu yang memiliki rasa kontrol yang tinggi akan dapat menghasilkan hasil belajar yang baik begitu juga sebaliknya seorang individu yang memiliki kontrol yang rendah maka cenderung akan mengalami kesulitan dalam belajar. 
Dari berbagai fenomena yang telah dijelaskan di atas, akan menjadi dasar pemikiran peneliti untuk dapat melakukan penelitian secara lebih mendalam mengenai efek mediasi sense of control pada pengaruh smartphone addiction terhadap academic procrastination studi pada siswa SMK Pasundan 1 Cianjur jurusan akuntansi. Dengan adanya penelitian ini diharapkan akan menjadi referensi untuk melakukan upaya pencegahan ataupun penanggulangan terjadinya prokrastinasi akademik siswa. Dengan demikian maka model yang ajukan dijelaskan dengan gambar sebagai berikut.

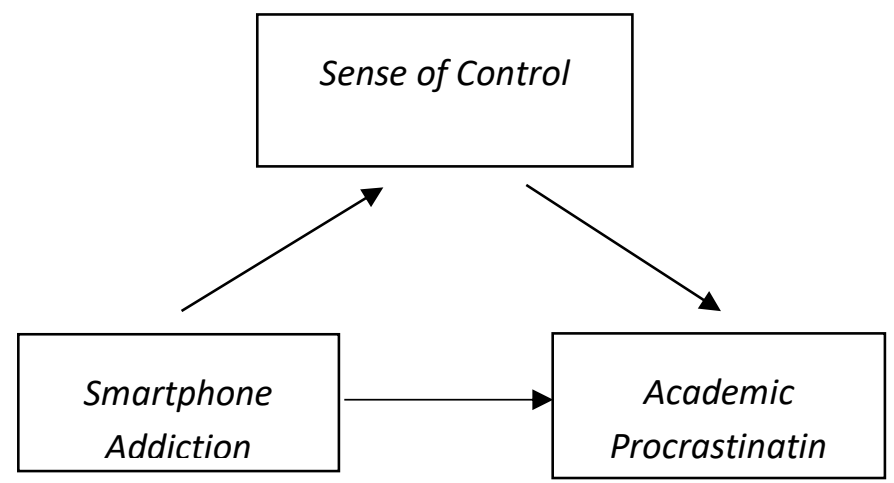

Gambar 1: Model Penelitian

\section{LANDASAN TEORI}

\section{Sense of control}

Sense of control merupakan faktor utama dan menjadi sentral dalam psikologi, di mana seorang individu dapat membentuk dan beradaptasi dengan variabel motivasi terhadap cara individu tersebut dalam mengatasi stres dalam hidupnya (Guo et al., 2016). Definisi yang lain menyebutkan bahwa sense of control merupakan sebuah rasa kendali diri atau pengendalian pikiran dan tindakan untuk dapat menahan dorongan yang ada pada diri seseorang untuk melakukan hal yang seharusnya tidak dilakukan dan memprioritaskan tindakan yang seharusnya dilakukan (Junaedi dalam Widyaningrum, Risma, 2021). Sementara menurut Mirowsky \& Ross (1990) Sense of control atau rasa kontrol adalah salah satu dimensi di mana kondisi sosial objektif membentuk pengalaman dengan keberhasilan dan kegagalan yang pada gilirannya berkontribusi pada harapan umum tentang kontrol pribadi dengan demikian kontrol yang dirasakan merupakan hubungan kognitif antara tujuan kondisi sosial dan pengalaman batin. Berdasarkan hasil penelitian yang dilakukan oleh Muflihah \& Sholihah (2019) menyatakan bahwa sense of control merupakan kondisi dasar untuk dapat menciptakan sebuah harapan pada diri seorang seorang dengan optimis. Optimisme inilah yang akan menjadi modal ataupun pemantik bagi seorang individu untuk mengembangkan potensi yang ada pada diri individu tersebut (Nilam, 2013).

Rasa kontrol yang ada pada diri seorang individu muncul manakala individu tersebut mampu merencanakan membimbing serta mengatur tindakan ke arah yang lebih baik. Adapun indikator dari sense of control menurut Putri et al. (2017) terdapat 6 indikator diantaranya yaitu kemampuan mengendalikan perhatian, menahan diri, 
kemampuan menyaring informasi kemampuan mengendalikan emosi kemampuan mengendalikan motivasi dan kemampuan mengendalikan lingkungan.

\section{Smartphone Addiction}

Pada awalnya istilah adiksi atau kecanduan mempunyai cakupan yang cukup sempit di mana kecanduan atau adiksi cenderung berkaitan dengan zat ataupun obatobatan, namun kemudian cakupan tersebut diperluas hingga menyentuh ranah non zat (Kwon et al., 2013). Salah satu bentuk perluasan dari istilah adiksi non zat adalah kecanduan terhadap suatu perilaku seperti halnya kecanduan olahraga atau belanja (Grant et al., 2010). Salah satu sub dari kecanduan perilaku adalah kecanduan teknologi yang menggambarkan perilaku adiksi seseorang terhadap perangkat teknologi seperti halnya komputer dan video game (Griffiths, 1995). Beberapa peneliti sebelumnya telah menyepakati bahwa kecanduan smartphone termasuk ke dalam kategori kecanduan teknologi, konsep tersebut didefinisikan sebagai sebuah ketergantungan obsesif seseorang pada smartphone yang kemudian pada akhirnya dapat mengakibatkan ketidaknyamanan hidup pada seorang individu (Al-Barashdi et al., 2015, Lee et al., 2015). Smartphone addiction atau kecanduan terhadap smartphone merupakan sebuah perilaku seorang individu yang mencirikan keterikatannya pada smartphone yang pada akhirnya akan menimbulkan masalah pada hubungan sosial seperti menarik diri serta adanya kesulitan pada saat melakukan aktivitas keseharian, gangguan inilah yang dinamakan sebagai gangguan kontrol impulsif pada diri seorang individu (Kwon et al., 2013).

Menurut Lestari \& Sulian (2020) menyatakan bahwa faktor-faktor yang dapat mempengaruhi adiksi seseorang terhadap smartphone adalah"

1. faktor internal yang mencakup sentisation seeking, self esteem, dan self control.

2. Faktor situasional yang mencakup stres kesedihan kejenuhan belajar kesepian kecemasan dan laser boredom.

3. Faktor sosial yang mencakup mandatory behavior, connected presence.

4. Faktor eksternal yang mana cakupannya adalah media

Adapun yang menjadi indikator seseorang telah mengalami perilaku adiksi terhadap smartphone yaitu ditandai dengan adanya gangguan aktivitas, antisipasi positif, penarikan, penggunaan berlebihan, orientasi syberspace, toleransi (Kwon et al., 2013).

\section{Academic Procrastintion}

Pada teori prokrastinasi para peneliti menggunakan konotasi prokrastinasi dengan fungsi yang berbeda. Setidaknya terdapat tujuh aspek yang berfungsi sebagai dasar dari perbedaan tersebut diantaranya yaitu sebagai berikut:

1. Tindakan penundaan akibat tindakan terselubung atau terbuka (Ferrary dalam Klingsieck, 2013).

2. Tindakan prokrastinasi dirasa perlu untuk kepentingan pribadi (C. Lay, 1986)

3. Perilaku prokrastinasi bersifat sukarela dan tidak bisa dipaksakan (Milgram et al., 1998)

4. Prokrastinasi dilakukan karena penyelesaiannya mempunyai maksud (C. H. Lay \& Schouwenburg, 1993)

5. Prokrastinasi itu tidak perlu atau tidak rasional (C. Lay, 1986) 
6. Perilaku Prokrastinasi dilakukan meskipun menyadari potensi negatif yang akan terjadi (Steel, 2007)

7. Prokrastinasi dilakukan biasanya disertai dengan ketidaknyamanan subjektif (Solomon \& Rothblum, 1984, Ferrari \& Tice, 2000).

Dari ketujuh aspek yang telah disebutkan Steel (2007) mendefinisikan secara luas bahwa prokrastinasi merupakan sebuah tindakan yang dilakukan oleh seorang individu dengan sukarela dari aktivitas yang perlu atau penting, smeskipun kenyataan bahwa seorang individu tersebut menyadari konsekuensi negatif lebih besar daripada konsekuensi positif dari sebuah tindakan prokrastinasi. Prokrastinasi terjadi pada setiap individu tidak memandang jenis kelamin status pekerjaan usia ataupun pelajar (Burka \& Yuen, 2008 dalam Balkis \& Duru, 2009). prokrastinasi sangat umum terjadi di berbagai lini kehidupan baik pada rumah tangga pribadi keuangan sosial pekerjaan ataupun akademik (Steel, 2007).

Sementara academic procrastination merupakan perilaku penundaan yang mengacu pada kecenderungan siswa untuk menunda-nunda kewajiban terkait dengan kegiatan akademik seperti halnya dalam penyelesaian tugas (Kandemir, 2014, Rabin et al., 2011, Steel, 2007) dari beberapa penelitian yang telah dilakukan bahwa terdapat beberapa faktor yang mempengaruhi prokrastinasi diantaranya yaitu, pengendalian diri, tingkat motivasi rendah, eksternal sebagai pusat kendali, manajemen waktu yang lemah, perfeksionis, penggunaan internet atau smartphone, self efficacy rendah kesadaran diri kecemasan sosial dan rasa takut gagal (Grant et al., 2010, Ackerman dan gross 2005, Philips 2007, odaci 2011, Ferrari dan mccrown 1994 dalam Aditya Chandra Bramandyta, 2021). Menurut Fauziah (2016) prokrastinasi akademik disebabkan oleh dua faktor yaitu faktor internal yang merupakan faktor yang berasal dari dalam diri seseorang yang mencakup faktor fisik dan psikologis, dan faktor eksternal yang merupakan faktor yang berasal dari luar dalam hal ini adalah lingkungan.

Sementara itu indikator prokrastinasi akademik menurut (Muyana, 2018, Mccloskey, 2011) diantaranya yaitu keyakinan terhadap kemampuan diri, gangguan perhatian, faktor sosial, manajemen waktu, inisiatif pribadi, dan kemalasan.

\section{METODOLOGI}

Penelitian ini dilakukan dengan menggunakan metode survei pendekatan regresi. Penelitian dengan menggunakan survei tujuan untuk mengetahui gambaran rinci secara umum mengenai objek penelitian dengan melihat data dan informasi yang ada pada sampel penelitian. Selain itu penelitian ini juga merupakan penelitian dengan tingkat eksplanasi asosiatif kausal dengan alat ukur statistik koefisien jalur (parh analysis) diimana penelitian ini bertujuan untuk mengetahui atau menganalisis efek mediasi sense of control pada pengaruh smartphone addiction terhadap academic procrastination. Sementara instrumen yang digunakan dalam penelitian ini yaitu berupa instrumen kuesioner yang berisi berbagai pernyataan dari ketiga variabel dengan indikator yang sudah ditetapkan.

Populasi dalam penelitian ini adalah siswa SMK Pasundan 1 Cianjur. Adapun sampel dalam penelitian ini adalah siswa akuntansi SMK Pasundan 1 Cianjur. teknik sampling yang digunakan adalah teknik proporsional random sampling di mana setiap 
siswa aktif SMK Pasundan 1 Cianjur yang memiliki peluang yang sama untuk dijadikan sampel. Pada penelitian ini sampel yang terkumpul sebanyak 123 siswa.

Teknik pengumpulan data pada penelitian ini menggunakan teknik komunikasi tidak langsung dengan inventori yang digunakan bersifat tertutup yang artinya sejumlah pernyataan yang yang ada pada setiap variabel telah disediakan alternatif jawaban untuk dipilih oleh responden sesuai dengan keadaan responden itu sendiri dengan menggunakan Google form. Selain itu inventory lain untuk dapat mengolah data yang sudah terkumpul peneliti menggunakan program IBM SPSS versi 25.

\section{HASIL DAN PEMBAHASAN}

HASIL

Berdasarkan hasil pengolahan data yang sudah terkumpul, di mana terdapat 6 indikator pada variabel smartphone addiction, 6 indikator pada variabel sense of control dan 6 variabel pada indikator academic procrastination. Adapun rincian gambaran umum setiap variabel yaitu sebagai berikut:

Tabel 1.

Gmbaran Smartphone addiction

\begin{tabular}{lccccc}
\hline Indiktor & Item & $\begin{array}{c}\text { Total } \\
\text { Ideal }\end{array}$ & $\begin{array}{c}\text { Skor } \\
\text { Aktual }\end{array}$ & $\%$ & Kategori \\
\hline Gangguan aktivitas, & 4 & 2460 & 1813 & 73,70 & Sedang \\
\hline Antisipasi positif, & 3 & 1845 & 1407 & 76,26 & Sedang \\
\hline Penarikan, & 3 & 1845 & 1250 & 67,75 & Rendah \\
\hline Penggunaan berlebihan, & 4 & 2460 & 1860 & 75,61 & Sedang \\
\hline Orientasi syberspace, & 4 & 2460 & 1623 & 65,98 & Rendah \\
\hline Toleransi & 5 & 3075 & 2180 & 70,89 & Sedang \\
\hline Total skor & & 14145 & 10133 & 71,64 & Sedang \\
\hline
\end{tabular}

Sumber : olah data excel

Tabel 2.

Gambaran Sense of control

\begin{tabular}{lccccc}
\hline \multicolumn{1}{c}{ Indiktor } & Item & $\begin{array}{c}\text { Total } \\
\text { Ideal }\end{array}$ & $\begin{array}{c}\text { Skor } \\
\text { Aktual }\end{array}$ & $\%$ & Kategori \\
\hline $\begin{array}{l}\text { kemampuan mengendalikan } \\
\text { perhatian, }\end{array}$ & 4 & 2460 & 1397 & 56,79 & Rendah \\
\hline $\begin{array}{l}\text { menahan diri, } \\
\text { kemampuan menyaring } \\
\text { informasi }\end{array}$ & 4 & 2460 & 1632 & 66,34 & Rendah \\
\hline $\begin{array}{l}\text { kemampuan mengendalikan } \\
\text { emosi }\end{array}$ & 5 & 3075 & 1939 & 63,06 & Rendah \\
\hline $\begin{array}{l}\text { kemampuan mengendalikan } \\
\text { motivasi }\end{array}$ & 5 & 3075 & 1861 & 60,52 & Rendah \\
\hline $\begin{array}{l}\text { kemampuan mengendalikan } \\
\text { lingkungan }\end{array}$ & 3 & 1845 & 1048 & 56,80 & Rendah \\
\hline \multicolumn{1}{c}{ Total skor } & 15375 & 9334 & 60,71 & Rendah \\
\hline
\end{tabular}

Sumber : olah data excel 
Tabel 3.

Gambaran Academic Procrastination

\begin{tabular}{lrrrrl}
\hline \multicolumn{1}{c}{ Indiktor } & Item & $\begin{array}{c}\text { Total } \\
\text { Ideal }\end{array}$ & $\begin{array}{c}\text { Skor } \\
\text { Aktual }\end{array}$ & $\%$ & Kategori \\
\hline $\begin{array}{l}\text { Keyakinan terhadap } \\
\text { kemampuan diri, }\end{array}$ & 3 & 1845 & 1308 & 70,89 & Sedang \\
\hline Gangguan perhatian, & 5 & 3075 & 2186 & 71,09 & Sedang \\
\hline Faktor sosial, & 3 & 1845 & 1328 & 71,98 & Sedang \\
\hline Manajemen waktu, & 5 & 3075 & 1997 & 64,94 & Rendah \\
\hline Inisiatif pribadi, & 4 & 2460 & 1802 & 73,25 & Sedang \\
\hline Kemalasan & 3 & 1845 & 1253 & 67,91 & Rendah \\
\hline \multicolumn{1}{c}{ Total skor } & & 14145 & 9874 & 69,81 & Sedang \\
\hline
\end{tabular}

Sumber : olah data excel

1. Uji Prasyarat Analisis

Uji Normalitas

Tabel 4.

Uji Normalitas

One-Sample Kolmogorov-Smirnov Test

Unstandardized Residual

\begin{tabular}{llr}
\hline N & & 123 \\
\hline \multirow{2}{*}{ Normal Parametersa,b } & Mean & .0000000 \\
\cline { 2 - 3 } & Std. Deviation & 8.78014118 \\
\cline { 2 - 3 } & Absolute & .043 \\
\cline { 2 - 3 } & Positive & .043 \\
\cline { 2 - 3 } Test Statistic & Negative & -.032 \\
\hline Asymp. Sig. (2-tailed) & & .043 \\
\hline
\end{tabular}

a. Test distribution is Normal.

b. Calculated from data.

c. Lilliefors Significance Correction.

d. This is a lower bound of the true significance.

Sumber : olah data SPSS versi 25

Berdasarkan hasil uji normalitas di atas hasil menunjukkan bahwa nilai signifikansi data dari variable penelitian adalah sebesar 0,200 , dengan demikian maka dapat disimpulkan bahwa data dari variabel-variabel penelitian ini berdistribusi normal mengingat tingkat signifikansi hasil uji normalitas lebih besar daripada 0,05 sehingga kemudian data tersebut dapat dipergunakan untuk melakukan hujan nanti selanjutnya. 


\section{Uji Asumsi Klasik}

Uji Multikolinearitas

Tabel 5.

Uji Multikolinearitas

\begin{tabular}{|c|c|c|c|c|c|c|}
\hline \multicolumn{7}{|c|}{ Coefficientsa } \\
\hline & & \multicolumn{2}{|c|}{$\begin{array}{l}\text { Unstandardized } \\
\text { Coefficients }\end{array}$} & \multirow[t]{2}{*}{ Sig. } & \multicolumn{2}{|c|}{$\begin{array}{c}\text { Collinearity } \\
\text { Statistics }\end{array}$} \\
\hline \multicolumn{2}{|c|}{ Model } & B & $\begin{array}{l}\text { Std. } \\
\text { Error }\end{array}$ & & $\begin{array}{c}\text { Toleranc } \\
\mathrm{e}\end{array}$ & VIF \\
\hline \multirow[t]{3}{*}{1} & (Constant) & 42.267 & 6.655 & .000 & & \\
\hline & Smartphne Addiction (X) & -.229 & .059 & .000 & .999 & 1.001 \\
\hline & Sense of Control (Z) & .673 & .058 & .000 & .999 & 1.001 \\
\hline
\end{tabular}

Sumber : olah data SPSS versi 25

Berdasarkan hasil uji multikolinearitas diatas, diketahui bahwa nilai toleransi pada variabel smartphone addiction adalah sebesar 0,999 sementara itu pada variabel sense of control nilai toleransi menunjukkan angka 0,999 di mana angka tersebut lebih besar daripada 0,01, selain itu untuk keputusan juga bisa diambil dari perbandingan antara VIP dengan ketetapan toleransi sebesar 10,00 dimana berdasarkan hasil uji multikolinearitas diatas nilai pada variabel smartphone addiction sebesar 1,001 dan pada variabel sense of control juga menunjukkan angka 1,001 di mana angka tersebut lebih kecil daripada 10,00 dengan demikian maka dapat disimpulkan bahwa model regresi pada variabel penelitian tersebut tidak memiliki masalah multikolinearitas.

\section{Uji Heteroskedastisitas}

Tabel 6.

Uji Heteroskedastisitas

\begin{tabular}{|c|c|c|c|c|}
\hline \multicolumn{5}{|c|}{ Coefficientsa } \\
\hline \multirow[b]{2}{*}{ Model } & \multicolumn{2}{|c|}{$\begin{array}{l}\text { Unstandardized } \\
\text { Coefficients }\end{array}$} & \multirow[t]{2}{*}{$t$} & \multirow[t]{2}{*}{ Sig. } \\
\hline & $\mathrm{B}$ & Std. Error & & \\
\hline (Constant) & -.071 & .467 & -.153 & .879 \\
\hline Smartphne Addiction (X) & .011 & .004 & 2.712 & .068 \\
\hline Sense of Control (Z) & .000 & .004 & .052 & .959 \\
\hline
\end{tabular}

Sumber : olah data SPSS versi 25

Berdasarkan berdasarkan hasil olah data uji heteroskedastisitas diketahui bahwa nilai signifikansi pada variabel smartphone addiction sebesar 0,068 selain itu pada variabel sense of control sebesar 0,959. Kedua angka tersebut lebih besar daripada 0,05 dengan demikian maka dapat disimpulkan bahwa variabel variabel penelitian tersebut tidak terjadi masalah heteroskedastisitas. 


\section{Uji Hipotesis \\ Uji Sobel}

Tabel 7.

Koefisisien Regresi Model Persamaan I

\section{Coefficientsa}

\begin{tabular}{lr|r|r|r|r} 
& \multicolumn{2}{c|}{$\begin{array}{c}\text { Unstandardized } \\
\text { Coefficients }\end{array}$} & $\begin{array}{c}\text { Standardized } \\
\text { Coefficients }\end{array}$ & $\mathrm{t}$ & \multicolumn{1}{c}{ Sig. } \\
& B & Std. Error & Beta & & \\
\hline 1 (Constant) & 77.729 & 7.540 & & 10.309 & .000 \\
\hline Smartphne Addiction $(X)$ & -.022 & .090 & -.023 & -.248 & .805 \\
\hline
\end{tabular}

a. Dependent Variable: Sense of Control (Z)

Sumber : olah data SPSS versi 25

Tabel 8.

Koefisisien Regresi Model Persamaan II

Coefficientsa

\begin{tabular}{lr|r|r|r|r} 
& \multicolumn{2}{c}{$\begin{array}{c}\text { Unstandardized } \\
\text { Coefficients }\end{array}$} & $\begin{array}{c}\text { Standardized } \\
\text { Coefficients }\end{array}$ & t & Sig. \\
& B & Std. Error & Beta & & \\
\hline 1 (Constant) & 42.267 & 6.655 & & 6.351 & .000 \\
\hline Smartphne Addiction (X) & .673 & .058 & .702 & 11.564 & .000 \\
\hline Sense of Control (Z) & -.229 & .059 & -.238 & -3.915 & .000 \\
\hline
\end{tabular}

a. Dependent Variable: Academic Procrastination (Y)

Sumber : olah data SPSS versi 25

Dari hasil uji regresi pada pengaruh Smartphone addiction terhadap sense of control (a) diketahui bahwa nilai koefisien regresi sebesar -0.022 dengan nilai standart error $\left(S E_{a}^{2}\right)$ sebesar 00.090 dan nilai signifikansi sebesr 0.805. Sementara itu pada variabel sense of control terhadap academic procrastination (b) memiliki niai koefisien sebesar -0.229 dengan standart error $\left(S E_{b}^{2}\right)$ sebesar 0.059 dan nilai signifikansi sebesar 0.000 .

Berdasarkan pengolahan data analisis regresi tersebut, maka dapat dibentuk persamaan Uji sobel sebagai berikut: 


$$
\mathrm{Z}=\frac{a b}{\sqrt{\left(a^{2} \times S E_{b}^{2}\right)+\left(b^{2} \times S E_{a}^{2}\right.}}
$$

Dengan menggunakan aplikasi http://quantpsy.org/sobel/sobel.htm diperoleh hasil sebagai berikut:

\begin{tabular}{|c|c|c|c|c|}
\hline Input: & & Test statistic: & Std. Error: & $p$-value: \\
\hline a -0.022 & Sobel test: & 0.2439611 & 0.02065083 & 0.80726095 \\
\hline$b-0.229$ & Aroian test: & 0.2362752 & 0.02132259 & 0.81321913 \\
\hline$s_{a} 0.090$ & Goodman test: & 0.25244942 & 0.01995647 & 0.80069371 \\
\hline$s_{\mathrm{b}} 0.059$ & Reset all & & Calculate & \\
\hline
\end{tabular}

Sumber : olah data http://quantpsy.org/sobel/sobel.htm

Dari hasil olah data tersebut maka dasar pengambilan keputusan dari uji hipotesis, dapat dilihat dari beberapa temua diantaranya:

a. Nilai koefisien pengaruh tidak langsung Smartphone addiction terhadap academic procrastination lebih kecil dari pada pengaruh langsung $X$ terhadap $Z(0,005267<$ $-.022)$

b. Nilai uji Z sebesar $0,244<1,96$

c. Nilai-p atau $p$-value sebesar $0,807>0,001$

Dari ketiga hasil olah data tersebut di atas, maka dapat disumpulkan bahwa Ho diterima dan $\mathrm{Ha}$ ditolah. dengan demikian $X$ (smartphone addiction) tidak berpengaruh signifikan terhadap $Y$ (academic procrastination) melalui $Z$ (sense of control). Dengan kata lain $Z$ bukan merupakan variabel intervening/variabel yang tidak kuat dalam memediasi hubungan $X$ terhadap $Y$. Hal ini menunjukan bahwa pengaruh yang sebenarnya adalah antara variabel $X$ (smartphone addiction) terhadap $Y$ (academic procrastination) yaitu pengaruh langsung.

Sehingga studi empirik yang dihasilkan dalam penelitian ini adalah sebagai berikut:
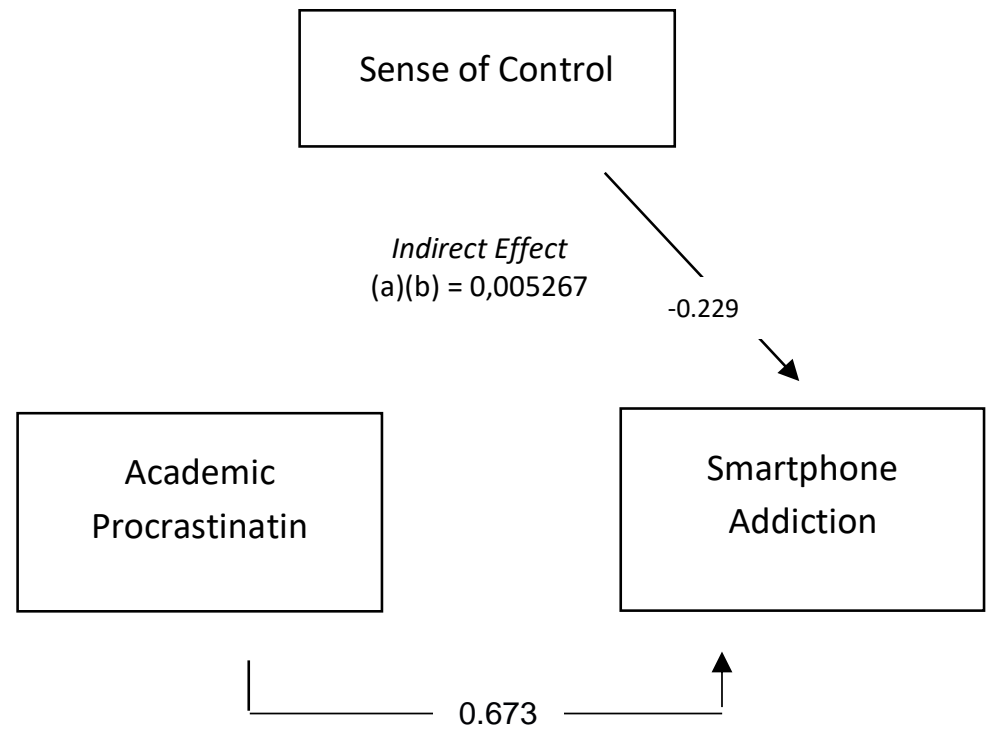

Gambar 1: Temuan Studi Empirik 


\section{PEMBAHASAN}

Berdasarkan hasil pengolahan data dari angket yang telah terkumpul dari 123 responden diketahui bahwa pada variabel smartphone addiction gambaran variabel sebesar $60,71 \%$ dengan kategori rendah. Indikator yang paling rendah pada variabel smartphone addiction adalah indikator Orientasi syberspace dengan skor sebesar $65,98 \%$, sementara indikator yang paling tinggi yaitu antisipasi positif dengan angka $76,26 \%$. Pada variable sense of control dan variabel sebesar $71,64 \%$ dengan kategori sedang. Pada variabel sense of control indikator yang paling rendah adalah kemampuan mengendalikan motivasi dengan angka 56,79\%, sementara indikator yang paling tinggi yaitu indikator menahan diri dengan angka $66,34 \%$. Pada variabel academic procrastination gambaran variabel sebesar $69,81 \%$ dengan kategori sedang. Pada variabel Academic procrastination indikator yang paling rendah ada pada indikator manajemen waktu yaitu sebesar $4,94 \%$ sementara indikator yang paling tinggi ada pada indikator inisiatif pribadi dengan angka $73,25 \%$.

Temuan pertama berdasarkan hasil pengolahan data untuk menjawab hipotesis 1 , angka pada koefisien regresi sebesar $-0,022$ dengan thitung sebesar $-0,248<t_{\text {tabel }}$ sebesar 1,657. Selain itu berdasarkan hasil uji signifikansi pada model ke-I sebesar 0,805 > 0,05 Yang mengartikan bahwa smartphone addiction tidak berpengaruh terhadap sense of control. Pada angka koefisien regresi hasil memang menunjukkan pengaruh negatif tapi sangat kecil, dengan ketetapan syarat pengambilan keputusan yang telah ditetapkan, maka penelitian ini menghasilkan tidak adanya pengaruh antara smartphone addiction terhadap sense of contro/ pada siswa jurusan akuntansi SMK Pasundan 1 Cianjur. Dengan demikian pada Hipotesis 1, HO diterima dan $\mathrm{Ha}$ ditolak. Hasil penelitian ini menolak penelitian sebelumnya yang dilakukan oleh Indriyani Wiji Utami (2019) yang mengatakan adanya hubungan dan pengaruh negatif antara smartphone addiction terhadap rasa kontrol. Tetapi penelitian ini mendukung penelitia sebelumnya yang menyatakan bahwa terdapat hubungan yang negative tetapi tidak signifikan (Debora \& Sukmawati, 2021).

Temuan kedua berdasarkan hasil pengolahan data untuk menjawab hipotesis 2 diketahui bahwa nilai koefisien regresi variabel sense of control pada model II bernilai $-0,229$ dengan $t_{\text {hitung }}$ sebesar $-3,915>t_{\text {tabel }}$ sebesar 1,657. Sementara berdasarkan hasil uji signifikansi pada model II sebesar 0,000 $<0,05$. Dengan demikian maka dapat diartikan bahwa sense of control berpengaruh negatif terhadap smartphone addiction pada siswa jurusan akuntansi SMK Pasundan 1 Cianjur. Dengan demikian pada hipotesis kedua Ha diterima dan $\mathrm{HO}$ ditolak. Penelitian ini mendukung penelitian sebelumnya yang dilakukan oleh Yosefhin Rika Ernima, Widya Parimita (2016), (Carden et al., 2004) Menyatakan adanya hubungan dan pengaruh negatif antara rasa kontrol terhadap penundaan akademik. Dimana semakin tinggi rasa kontrol, maka akan semakin rendah penundaan ataupun prokrastinasi akademik, begitu juga sebaliknya semakin rendah rasa kontrol akan semakin tinggi tingkat prokrastinasi akademik. Selain itu (Suharsono, 2013) mengemukakan bahwa rasa kontrol diri yang rendah akan mengakibatkan seseorang untuk melakukan kegiatan yang dianggap lebih menyenangkan daripada melakukan kegiatan yang seharusnya dan penting. Sebagai contoh seorang individu yang tidak mampu mengendalikan dirinya untuk dapat bertindak secara positif dan dapat mengerjakan tugas yang diberikan oleh guru (Syahriani \& Laksmiwati 2017 dalam Safiinatunnajah 
\& Fikry, 2021). Terkadang seorang siswa melakukan penundaan akademik bukan karena pengetahuan ataupun keterampilan yang kurang melainkan kemauan dan kepercayaan diri untuk dapat berhasil mendapatkan pengetahuan dan keterampilan tersebut (Klassen et al., 2008). Dengan demikian, patut adanya seorang siswa untuk dapat mengetahui dan merubah mind set siwa dalam belajar. Bahwa hal yang sebenarnya adalah bukan siswa belajar harus bisa.melainkan siswa belajar untuk bisa,

Temuan ketiga untuk dapat menjawab hipotesis 3 , berdasarkan hasil pengolahan data diketahui bahwa nilai koefisien regresi variabel smartphone addiction pada model II bernilai 0,673 dengan thitung sebesar 11,564 $>t_{\text {tabel }}$ sebesar 1,657. Selain itu berdasarkan hasil uji signifikansi pada model kedua variabel smartphone addiction sebesar $0,000<0,05$ dengan demikian maka dapat disimpulkan bahwa smartphone addiction berpengaruh positif terhadap academic procrastination pada siswa jurusan akuntansi SMK Pasundan 1 Cianjur. Dengan demikian hipotesis $3 \mathrm{Ha}$ diterima dan $\mathrm{HO}$ ditolak. Temuan ini sejalan dengan penelitian sebelumya yang dilakukan oleh Akinci (2021), Bakri (2021) yang menyatakan bahwa adanya pengaruh yang signifikan antara kecanduan gadget terhadap penundaan akademik. Selain itu temuan ini sejalan juga dengan pernyataan dari (Davis et al., 2002) seringkali tugas atau pekerjaan dapat menimbulkan rasa stres secara kognitif. Untuk mengatasi hal tersebut seorang individu akan melakukan aktivitas yang dianggap menyenangkan dengan cara bermain media sosial maupun media online lainnya. Ditambah lagi dengan pernyataan yang dikemukakan oleh (Rozgonjuk et al., 2018) yang menyatakan bahwa seringkali penggunaan smartphone yang berlebihan menyebabkan perilaku disfungsional seperti halnya penundaan atau prokrastinasi.

Temuan keempat untuk menjawab hipotesis 4 berdasarkan hasil pengolahan data diketahui bahwa bahwa nilai koefisien regresi sebesar -0.022 dengan nilai standart error $\left(S E_{a}^{2}\right)$ sebesar 00.090 dan nilai signifikansi sebesr 0.805 . Sementara itu pada variabel sense of control terhadap academic procrastination (b) memiliki niai koefisien sebesar -0.229 dengan standart error $\left(S E_{b}^{2}\right)$ sebesar 0.059 dan nilai signifikansi sebesar 0.000 . dengan menggunakan persamaaan:

$$
\mathrm{Z}=\frac{a b}{\sqrt{\left(a^{2} \times S E_{b}^{2}\right)+\left(b^{2} \times S E_{a}^{2}\right.}}
$$

Dan bantuan aplikasi http://quantpsy.org/sobel/sobel.htm diketahu bahwa hasil yang akan dijadikan sebagai bahan keputusan yaitu Nilai koefisien pengaruh tidak langsung Smartphone addiction terhadap academic procrastination lebih kecil dari pada pengaruh langsung $X$ terhadap $Z(0,005267<-.022)$ selain itu Nilai uji $Z$ sebesar $0,244<1,96$, disamping itu, Nilai-p atau $p$-value sebesar $0,807>0,001$. Dengan demikian maka dapat disumpulkan bahwa $X$ (smartphone addiction) tidak berpengaruh signifikan terhadap $Y$ (academic procrastination) melalui Z (sense of control). Dengan kata lain $Z$ bukan merupakan variabel intervening/variabel yang tidak kuat dalam memediasi hubungan $X$ terhadap $Y$. $\mathrm{Hal}$ ini menunjukan bahwa pengaruh yang sebenarnya adalah antara variabel $X$ (smartphone addiction) terhadap $\mathrm{Y}$ (academic procrastination) yaitu pengaruh 
langsung. Dengan demikian hipotesis 4 berkesimpulan $\mathrm{HO}$ diterima dan $\mathrm{Ha}$ ditolak. Hasil penelitian ini menolak hasil penelitian yang dilakukan oleh Krause et al. (1998) menyatakan bahwa pada umumnya rasa control memediasi hubungan dari hasil stressor. Stressor dalam penelitian ini adalah variabel smartphone addiction dan academic procrastination yang seringkali pada praktiknya seorang individu merasakan stres yang berlebihan. Selain itu juga hasil penelitian inipun menolak penelitian yang dilakukan oleh Zarzycka et al. (2021) dan Della Arny Novera (2018) menyatakan bahwa sense of control memediasi perilaku prokrastinasi.

\section{PENUTUP \\ Kesimpulan}

Berdasarkan hasil pengujian analisis data dan pengajuan hipotesis yang diajukan mengenai efek media sizes of control pada pengaruh smartphone addiction terhadap academic procrastination pada siswa SMK Pasundan 1 Cianjur jurusan akuntansi maka dapat diketahui bahwa :

1. Umunya tingkat adiksi gadget atau smartphone addiction pada siswa jurusan akuntansi SMK Pasundan 1 Cianjur berada dalam kategori sedang, tingkat rasa kontrol atau sense of control siswa SMK Pasundan 1 Cianjur jurusan akuntansi rata-rata berada pada kategori rendah. Sementara tingkat perilaku penundaan atau prokrastinasi akademik pada siswa SMK 1 Cianjur jurusan akuntansi berada pada kategori sedang.

2. Berdasarkan hasil uji analisis pengujian hipotesis ( $u j i \mathrm{~T}$ ) tidak terdapat pengaruh negatif smartphone addiction terhadap sense of control siswa jurusan akuntansi SMK Pasundan 1 Cianjur.

3. Berdasarkan hasil uji analisis pengujian hipotesis ( $u j i \mathrm{~T}$ ) terdapat pengaruh negatif antara sense of control terhadap academic procrastination siswa jurusan akuntansi SMK Pasundan 1 Cianjur.

4. Berdasarkan hasil uji analisis pengujian hipotesis (uji T) terdapat pengaruh positif antara smartphone addiction terhadap academic procrastination siswa jurusan akuntansi SMK Pasundan 1 Cianjur.

5. Berdasarkan hasil pengujian hipotesis (uji Z) diketahui bahwa smartphone addiction tidak berpengaruh signifikan terhadap academic procrastination melalui sense of control siswa jurusan akuntansi SMK Pasundan 1 Cianjur. Hal ini menunjukkan bahwa pengakuan sebenarnya adalah smartphone addiction terhadap academic procrastination dengan pengaruh langsung

\section{Saran}

Berdasarkan hasil temuan penelitian, adapun saran yang diberikan dalam penelitian ini adalah pada variabel smartphone addiction siswa harus menurunkan antisipasi positif sebagai indikator yang paling mendominasi. Pada variable sense of control siswa harus meningkatkan kemampuan mengendalikan perhatian sebagai indikator yang paling rendah, selain itu pada variabel academic procrastination siswa harus menurunkan tingkat inisiatif pribadi sebagai indikator yang paling mendominasi 


\section{DAFTAR PUSTAKA}

\section{Buku:}

Djamarah, S. B. (2011). Psikologi Belajar. Jakarta: Rineka Cipta.

Nilam, W. (2013). Kunci Pengembangan Diri (p. 5). Jakarta: Elex Media Komputindo. Santrock, W. J. (2007). Life span development: Perkembangan masa hidup jilid 2. Jakarta: Erlangga.

Suryono \& Hariyanto. (2011). Belajar dan Pembelajaran Teori dan Konsep Dasar. Bandung: Rosda.

\section{Jurnal:}

Aditya Chandra Bramandyta, O. U. (2021). EFFECT OF SELF-EFFECTION, SELFCONTROL AND PEER GROUP ON ACADEMIC PROCRASTINATION IN FACULTY OF ECONOMICS STUDENTS OF THE STATE UNIVERSITY OF JAKARTA. Self-Control and Peer Group on Academic Procrastination in Faculty of Economics Students of the State University of Jakarta, 1-25.

Akinci, T. (2021). Determination of Predictive Relationships Between Problematic Smartphone use, Self-Regulation, Academic Procrastination and Academic Stress Through Modelling. International Journal of Progressive Education, 17(1), 2021. https://doi.org/10.29329/ijpe.2020.329.3

Al-Barashdi, H., Bouazza, A., \& Jabur, N. (2015). Smartphone Addiction among University Undergraduates: A Literature Review. Journal of Scientific Research and Reports, 4(3), 210-225. https://doi.org/10.9734/jsrr/2015/12245

Bakri, R. P. (2021). Pengaruh Stres Akademik dan Kecanduan Smartphone Terhadap Prokrastinasi Akademik. Psikoborneo: Jurnal IImiah Psikologi, 9(3), 578-593. https://doi.org/10.30872/psikoborneo

Balkis, M., \& Duru, E. (2009). Prevalence of Academic Procrastination Behavior Among Pre-Service Teachers, and Its Relationship With Demographics and Individual Preferences. Journal of Theory \& Practice in Education (JTPE), 5(1), 18-32.

Carden, R., Bryant, C., \& Moss, R. (2004). Procrastination , and Achievement Among College Students '. Psychological Reports, 95, 581-582.

Choi, S. W., Kim, D. J., Choi, J. S., Ahn, H., Choi, E. J., Song, W. Y., Kim, S., \& Youn, H. (2015). Comparison of risk and protective factors associated with smartphone addiction and Internet addiction. Journal of Behavioral Addictions, 4(4), 308-314. https://doi.org/10.1556/2006.4.2015.043

Davis, R. A., Flett, G. L., \& Besser, A. (2002). Validation of a new scale for measuring problematic internet use: Implications for pre-employment screening. Cyberpsychology and Behavior, 5(4), 331-345. https://doi.org/10.1089/109493102760275581

Debora, N., \& Sukmawati, I. (2021). The Relationship Of Self Control To Students Gadget Use. 3(2), 129-133. https://doi.org/10.24036/00431kons2021 
Della Arny Novera, P. T. (2018). PERAN KONTROL DIRI DALAM MEMEDIASI PENGARUH MOTIVASI BERPRESTASI, PERFEKSIONISME, DAN KESULITAN EKONOMI TERHADAP PROKRASTINASI AKADEMIK (Studi Kasus pada Mahasiswa yang Sedang Mengerjakan Skripsi FE UNNES). Economic Education Analysis Journal, 7(1), 45-58.

Ferrari, J. R., \& Tice, D. M. (2000). Procrastination as a self-handicap for men and women: A task-avoidance strategy in a laboratory setting. Journal of Research in Personality, 34(1), 73-83. https://doi.org/10.1006/jrpe.1999.2261

Geng, J., Han, L., Gao, F., Jou, M., \& Huang, C. C. (2018). Internet addiction and procrastination among Chinese young adults: A moderated mediation model. Computers in Human Behavior, 84, 320-333. https://doi.org/10.1016/j.chb.2018.03.013

Grant, J. E., Potenza, M. N., Weinstein, A., \& Gorelick, D. A. (2010). Introduction to behavioral addictions. American Journal of Drug and Alcohol Abuse, 36(5), 233241. https://doi.org/10.3109/00952990.2010.491884

Griffiths, M. (1995). Technological addictions. Clinical Psychology Forum, 76(January 1995), 14-19.

Guo, X., Egan, V., \& Zhang, J. (2016). Sense of control and adolescents' aggression: The role of aggressive cues. PsyCh Journal, 5(4), 263-274. https://doi.org/10.1002/pchj.151

INDRIYANI WIJI UTAMI. (2019). Hubungan Internal Locus of Control Dengan Tendensi Kecanduan Game Online Pada Remaja Akhir Di Klaten Skripsi. http://repository.unwidha.ac.id/1730/

Kandemir, M. (2014). The predictors of academic procrastination: Responsibility, attributional styles regarding success / failure, and beliefs in academic selfefficacy. Egitim ve Bilim, 39(171), 99-114.

Khoury, J. M., Couto, L. F. S. C., De Almeida Santos, D., De Oliveira e Silva, V. H., Drumond, J. P. S., De Carvalho e Silva, L. L., Malloy-Diniz, L., Albuquerque, M. R., De Castro Lourenço das Neves, M., \& Garcia, F. D. (2019). Bad choices make good stories: The impaired decision-making process and skin conductance response in subjects with smartphone addiction. Frontiers in Psychiatry, 10(FEB), 1-10. https://doi.org/10.3389/fpsyt.2019.00073

Klassen, R. M., Krawchuk, L. L., \& Rajani, S. (2008). Academic procrastination of undergraduates: Low self-efficacy to self-regulate predicts higher levels of procrastination. Contemporary Educational Psychology, 33(4), 915-931. https://doi.org/10.1016/j.cedpsych.2007.07.001

Klingsieck, K. B. (2013). Procrastination in Different Life-Domains: Is Procrastination Domain Specific? Current Psychology, 32(2), 175-185. https://doi.org/10.1007/s12144-013-9171-8

Krause, N., Liang, J., \& Gu, S. (1998). Financial strain, received support, anticipated support, and depressive symptoms in the People's Republic of China. Psychology and Aging, 13(1), 58-68. https://doi.org/10.1037/0882-7974.13.1.58

Kwon, M., Lee, J. Y., Won, W. Y., Park, J. W., Min, J. A., Hahn, C., Gu, X., Choi, J. H., \& Kim, D. J. (2013). Development and Validation of a Smartphone Addiction Scale (SAS). PLoS ONE, 8(2). https://doi.org/10.1371/journal.pone.0056936 
Lay, C. (1986). At last, my research article on procrastination.Journal of Research in Personality. Journal of Research in Personality, 20(4), 474-495.

Lay, C. H., \& Schouwenburg, H. C. (1993). Trait procrastination, time management, and academic behavior. Journal of Social Behavior \& Personality, 8(4), 647-662.

Lee, J., Cho, B., Kim, Y., \& Noh, J. (2015). Smartphone addiction in university students and its implication for learning. Lecture Notes in Educational Technology, 9783662441879, 297-305. https://doi.org/10.1007/978-3-66244188-6_40

Lestari, R., \& Sulian, I. (2020). Faktor-Faktor Penyebab Siswa Kecanduan Handphone Studi Deskriptif Pada Siswa Di Smp Negeri 13 Kota Bengkulu. Consilia: Jurnal Ilmiah Bimbingan Dan Konseling, 3(1), 23-37. https://doi.org/10.33369/consilia.v3i1.9473

Maison, M., Kurniawan, D. A., \& Anggraini, L. (2021). Perception, Attitude, and Student Awareness in Working on Online Tasks During the Covid-19 Pandemic. Jurnal Pendidikan Sains Indonesia (Indonesian Journal of Science Education), 9(1), 108-118. https://doi.org/10.24815/jpsi.v9i1.18039

Mccloskey. (2011). my thesis on academic procrastination. December.

Meiliza Purwanti, Purwanti, S. L. (2016). Pengaruh Kontrol Diri terhadap Prokrastinasi Akademik Peserta Didik Kelas X SMA Negeri 1 Sungai Ambawang. Jurnal Pendidikan Dan Pembelajaran Khatulitiwa, 1-15.

Milgram, N., Mey-Tal, G., \& Levison, Y. (1998). Procrastination, generalized or specific, in college students and their parents. Personality and Individual Differences, 25(2), 297-316. https://doi.org/10.1016/S0191-8869(98)00044-0

Mirowsky, J., \& Ross, C. E. (1990). The Consolation-Prize Theory of Alienation. American Journal of Sociology, 95(6), 1505-1535. https://doi.org/10.1086/229462

Muflihah, F., \& Sholihah, A. (2019). TRIADIK, VOLUME 18, No.1, APRIL 2019. Prodi Bimbingan Dan Konseling Fakultas Keguruan Dan IImu Pendidikan Universitas Bengkulu, 18(1).

Muhid, A. (2009). Hubungan antara self control dan self efificiacy dengan kecenderungan perilaku prokrastinasi akademik mahasiswa. Jurnal Psikologi Pendidikan Dan Bimbingan, 10(1), 1-15.

Muyana, S. (2018). Prokrastinasi akademik dikalangan mahasiswa program studi bimbingan dan konseling. Counsellia: Jurnal Bimbingan Dan Konseling, 8(1), 45. https://doi.org/10.25273/counsellia.v8i1.1868

Pierce, T. A., \& Vaca, R. (2007). Distracted: Academic performance differences between teen users and non-users of MySpace and other communication technology. IMSCI 2007 - International Multi-Conference on Society, Cybernetics and Informatics, Proceedings, 1, 295-299.

Putri, M. S., Daharnis, D., \& Zikra, Z. (2017). Hubungan Kontrol Diri dengan Perilaku Membolos Siswa. Konselor, 6(1), 1. https://doi.org/10.24036/02017616441-0-00

Rabin, L. A., Fogel, J., \& Nutter-Upham, K. E. (2011). Academic procrastination in college students: The role of self-reported executive function. Journal of Clinical and Experimental Neuropsychology, 33(3), 344-357. https://doi.org/10.1080/13803395.2010.518597 
Rozgonjuk, D., Kattago, M., \& Täht, K. (2018). Social media use in lectures mediates the relationship between procrastination and problematic smartphone use. Computers in Human Behavior, 89, 191-198. https://doi.org/10.1016/j.chb.2018.08.003

Sa, B., Ojeh, N., Majumder, M. A. A., Nunes, P., Williams, S., Rao, S. R., \& Youssef, F. F. (2019). The Relationship Between Self-Esteem, Emotional Intelligence, and Empathy Among Students From Six Health Professional Programs. Teaching and Learning in Medicine, 31(5), 536-543. https://doi.org/10.1080/10401334.2019.1607741

Sabir, O. and M. C. (2007). The Effects of Race and Family Attachment on SelfEsteem, Self-Control, and Delinquency. In LFB Scholarly Publishing LLC. LFB Scholarly Publishing LLC.

Safiinatunnajah, R., \& Fikry, Z. (2021). Hubungan Antara Kontrol Diri dengan Prokrastinasi Akademik pada Siswa Pengguna Media Sosial. Jurnal Pendidikan Tambusai, 5(2013), 228-233.

Solomon, L. J., \& Rothblum, E. D. (1984). Academic procrastination: Frequency and cognitive-behavioral correlates. Journal of Counseling Psychology, 31(4), 503509. https://doi.org/10.1037//0022-0167.31.4.503

Steel, P. (2007). The nature of procrastination: A meta-analytic and theoretical review of quintessential self-regulatory failure. Psychological Bulletin, 133(1), 65-94. https://doi.org/10.1037/0033-2909.133.1.65

Suharsono, S. (2013). self-Regulated Learning (SRL) dengan Prokrastnasi Akademic pada Siswa Akselerasi. Jurnal Ilmiah Psikologi Terapan, 01(01), 66-75.

Umar, W. R., Rahayu, A. S., \& Firmansyah, D. (2018). Dampak Sistem Kebut Semalam Terhadap Tingkat Plagiarisme Tugas Mahasiswa IKIP Siliwangi. Parole (Jurnal Pendidikan Bahasa Dan Sastra Indonesia), 1(4), 497-502. https://journal.ikipsiliwangi.ac.id/index.php/parole/article/view/849

Widyaningrum, Risma, T. S. (2021). Hubungan Antara Kontrol Diri dan Efikasi Diri Dengan Prokrastinasi Akademik Pada Siswa Kelas XI SMAIT Raflesia Depok. Jurnal Sosial Dan Humaniora, 5(2013), 228-233. https://journals.upiyai.ac.id/index.php/ikraith-humaniora/article/download/953/742

Yosefhin Rika Ernima, Widya Parimita, A. W. (2016). LOCUS OF CONTROL DAN PROKRASTINASI PADA MAHASISWA PENDIDIKAN EKONOMI ANGKATAN 2013 FAKULTAS EKONOMI UNIVERSITAS NEGERI JAKARTA. Jurnal Pendidikan Ekonomi Dan Bisnis, 4(2), 87-106.

Zarzycka, B., Liszewski, T., \& Marzel, M. (2021). Religion and behavioral procrastination: Mediating effects of locus of control and content of prayer. Current Psychology, 40(7), 3216-3225. https://doi.org/10.1007/s12144-01900251-8 